\title{
Biological Activity of Phenolic Compounds from Argentinean Herbs Infusions
}

\author{
María J. Rodríguez-Vaquero", Claudia V. Vallejo and Pedro A. Aredes-Fernandez
}

Facultad de Bioquímica, Química y Farmacia, Universidad Nacional de Tucumán, Ayacucho 471, (4000) Tucumán, Argentina

\begin{abstract}
Argentinean herbal infusions were studied for their beneficial biological properties and secondary metabolites content, such as phenolic compounds in order to find new natural products beneficial. The modifications of antihypertensive and antioxidant activities by the addition of commonly used additives (lemon, sugar and sweetener) were studied also.

Ilex paraguaiensis infusion showed the highest concentration of phenolic compounds and flavonoid fraction, the supplementation with lemon juice increased the phenolic compound content. All infusion showed high DPPH radical scavenging assays and additives did not modify significantly this activity. The infusion of I. paraguaiensis presents the maximum viability reduction of Escherichia coli and Staphylococcus aureus and the herbs combination Lippia integrifolia-Ilex paraguaiensis was the most effective to reduce $S$. aureus and E.coli viability. The phenolic compounds concentration as well as the qualitative composition of each infusion plays an important role in the antimicrobial activity. Because the high correlation between the concentration of total phenolic compounds and antioxidant and antihypertensive activities, we can infer that the phenolic compounds are responsible for such activities. The results obtained allow us to propose the herbs studied as potential natural antioxidants and antihypertensive compounds that could be used in pharmaceutical and food industries.
\end{abstract}

Keywords: Antibacterial capacity, antihypertensive properties, antioxidant activity, herbs infusions, phenolic compounds.

\section{INTRODUCTION}

Tea (Camellia sinensis) is one of the most consumed beverages worldwide after water and as a result, a variety of herbs or herb mixtures have emerged.

Herbs and their derivatives are used in nutrition, medicine, cosmetics fragrances, repellents, flavouring and beverages [1]. The herb infusions are an important source of phenolic compounds [2-4]. Herbs contain phenolic compounds, which are bioactive substances in vegetables, food and derived products because of their human health protecting capacity.

The chemical structure and the biodistribution of the phenolic compounds in the body are responsible for the biological properties and bioavailability of these compounds $[5,6]$. No studies about the antihypertensive activity of Argentinean herb infusions or the modification produced in antihypertensive or antioxidant activities due to the use of additives in herb infusions were reported till now.

The aim of this study was to investigate the antihypertensive, antioxidant and antibacterial properties of different Argentinean herbs infusions consumed traditionally; and the modifications for the use of three

*Address correspondence to this author at the Facultad de Bioquímica, Química y Farmacia. Universidad Nacional de Tucumán, Ayacucho 471, (4000) Tucumán, Argentina; Tel: 54-381-4247752 - ext. 7067;

Fax: 54-381-4248169; E-mail: mariajo@ @bqf.unt.edu.ar additives (sugar, sweetener and lemon) commonly used during herbal infusion consumption in Argentine during these activities.

\section{MATERIALS AND METHODS}

\section{Argentinean Herb Samples}

Herbs samples were obtained commercially from pharmacy in Argentinean. Lippia integrifolia, Mentha piperita, Lippia turbinata, Wendtia Calysina, Chenopodioum ambrosioides, Minthostachys verticillatta, Peumus boldus, Aloysia citriodora and Ilex paraguaiensis herbs were selected. A combination of herbs called digestive, contain: Lippia integrifolia 20\%, Lippia turbinata 20\%, Wendtia calysina 20\%, Chenopodioum ambrosioides $20 \%$ and Minthostachys verticillatta 20\%. Lemon, sugar and sweetener were obtained from local commercial.

\section{Herbs Infusions Elaboration}

Herbal infusions were prepared as consumed in Argentinean. Individual herbs $(2 \mathrm{~g})$ were added to $(250 \mathrm{~mL})$ of water heated to $90^{\circ} \mathrm{C}$ for $10 \mathrm{~min}$. The infusions were filtered using cotton. An aliquot of the infusions was clarified using activated charcoal $(30 \mathrm{mg} / \mathrm{L})$ and sterile filtered.

Selected herb mixtures were elaborated by the same procedure, weighing $1 \mathrm{~g}$ of each herb and then adding 250 
$\mathrm{mL}$ boiling water. A spoonful of lemon, sugar or sweetener was added to the infusion.

For the tests of antimicrobial activity, different herbs infusions were concentrated, weighing $4 \mathrm{~g}$ of each herb and dissolved in $250 \mathrm{~mL}$ boiling water.

\section{Concentration of Phenolic Compounds in Herb Infusi- ons}

To determine the concentration of total phenolic compounds, the method described by Singleton and Rossi [7] was used. The measurements were carried out in triplicate and results were expressed as milligram of gallic acid equivalents per liter (GAE) using a standard curve of gallic acid.

To discriminate the concentration of phenolic acids and flavonoid compounds in infusions, $10 \mathrm{~mL}$ of infusion was mixed with $10 \mathrm{~mL}$ of diluted solution of $\mathrm{HCl}(1: 3)$ and $5 \mathrm{~mL}$ formaldehyde solution $(8 \mathrm{mg} / \mathrm{mL})$. The mixture was incubated 24 hours at room temperature in order to precipitate the flavonoid fraction [8]. The concentration of phenolic acids in the supernatant was determined using the technique of Singleton and Rossi, while the concentration of flavonoid compounds was determined by difference between the concentration of total phenolic compounds and phenolic acids. The results were expressed as $\mathrm{mg} / \mathrm{L}$ of gallic acid equivalents (GAE). The phenolic compounds concentrations were confirmed by HPLC analysis, using a Knauer Smartline system chromatograph. The chromatographic conditions were as follows: reprosil-Pur ODS-3 (250 x $4.6 \mathrm{~mm})$, flow rate $1.0 \mathrm{~mL} / \mathrm{min}$, injection volume $20 \mu \mathrm{L}$, detection wavelength $280 \mathrm{~nm}$. Phase A (phosphoric acid 0,1\%) and phase $\mathrm{B}\left(\mathrm{CH}_{3} \mathrm{CN}\right)$.

\section{ACE-Inhibitory (ACEI) Activity}

ACEI activity was determined using the method described by Cushman and Cheung [9] and later modified by Hernández-Ledesma et al. [10]. This technique is based on the quantification of hippuric acid formed by the reaction of hippuryl-histidyl-leucine (HHL) with ACE in the presence and absence of an inhibitor. An aliquot of $110 \mu \mathrm{L}$ of substrate, $10 \mathrm{mM}$ HHL dissolved in buffer (0.2 M phosphate and $0.3 \mathrm{M} \mathrm{NaCl}, \mathrm{pH} \mathrm{8.3)}$, and $25 \mu \mathrm{L}$ of ACE $(26 \mathrm{mU}$ dissolved in $50 \%$ glycerol) were added to $15 \mu \mathrm{L}$ of samples (source of ACE inhibitor). The reaction mixture was incubated at $37^{\circ} \mathrm{C}$ for $80 \mathrm{~min}$ and then the enzyme reaction was stopped by the addition of $110 \mu \mathrm{L}$ of $1 \mathrm{~N} \mathrm{HCl}$. The hippuric acid formed was extracted with $1 \mathrm{~mL}$ of ethyl acetate, shaken and subsequently centrifuged at $5000 \mathrm{~g}$ for $10 \mathrm{~min}$. A $750-\mu \mathrm{L}$ of the organic layer was dried at $45^{\circ} \mathrm{C}$ in a vacuum chamber $(-60 \mathrm{~cm} \mathrm{Hg})$ for $60 \mathrm{~min}$. The residue was redissolved in $1 \mathrm{~mL}$ of distilled water and absorbance was measured at $228 \mathrm{~nm}$. A reaction blank was obtained by the addition of $\mathrm{HCl}$ before ACE enzyme activity. Interference of compounds with absorbance at this wavelength was eliminated with a sample blank. ACEI activity is expressed as follows:

$\%$ of $\mathrm{ACEI}=100[(A-B)-(C-D)] /(A-B)$

Where, A represents the absorbance in the presence of ACE, $\mathrm{B}$ the absorbance of the reaction blank, $\mathrm{C}$ the absorbance in the presence of ACE and inhibitor and D absorbance of the sample blank.

\section{Antioxidant Activity}

\section{Ferric-reducing Antioxidant Power Assay (FRAP).}

The ferric-reducing ability (FRAP) of the samples was determined using the proposed method by Benzie and Strain [11] with some modifications. The method measures the ability of the sample to reduce a complex of ferric iron with tripyridyl-s-triazine molecule (TPTZ) in the ferrous form. The intensity of color is proportional to the reducing activity of the sample, which is measured spectrophometrically at $593 \mathrm{~nm}$. A standard curve of ferrous sulfate $(100-3500 \mu \mathrm{M}$ $\mathrm{FeSO}_{4}$ ) was used. The FRAP reagent was freshly prepared daily by mixing acetate buffer ( $\mathrm{pH} 3.6), 10 \mathrm{mmoL}$ TPTZ solution in $40 \mathrm{mmoL} \mathrm{HCl}$ and $20 \mathrm{mmoL} F$ (III) chloride solution in the proportions of 10:1:1 (v/v), respectively. The reagent was warmed to $37^{\circ} \mathrm{C}$ in a water bath prior to use. Fifty microliters of the samples were added to $1.5 \mathrm{~mL}$ of FRAP reagent and incubated for 4 minutes. Measurements were made in triplicate and the results expressed as $\mu \mathrm{moL} / \mathrm{L}$ FeSO4.

Antioxidant activity of the samples was measured according to the free radical scavenging capacity DPPH (1,1diphenyl-2-picrilhydrazyl), using the method proposed by Von Gadow et al. [12]. An aliquot of $50 \mu \mathrm{L}$ of sample was mixed with $2 \mathrm{ml}$ of a methanol solution of DPPH radical. Absorbance measurements were performed immediately and after 15 minutes of incubation at $517 \mathrm{~nm}$. Methanolic solutions of trolox were tested. All measurements were made in triplicate.

Antioxidant activity of the samples was also measured according to the free radical scavenging capacity ABTS. (2,2'-azinobis-(3- ethylbenzothiazoline-6-sulfonate)), using the method proposed by $\mathrm{Re}$ et al. [13], with slight modifications. Absorbance was measured after 6 minutes incubation at $734 \mathrm{~nm}$. Standard curve of ascorbic acid (0 - 20 $\mathrm{mmoL} / \mathrm{L})$ was also evaluated against the radical. Results were expressed as scavenged activity of ABTS radical (\%), equivalent in ascorbic acid.

\section{Antibacterial Activity}

Microorganisms and culture conditions. The bacterial strain used was Escherichia coli ATCC 35218. The bacteria used in each experiment were cultured at $37^{\circ} \mathrm{C}$ in nutrient broth and agar broth containing in $\mathrm{g} / \mathrm{L}$ : beef extract, 3.0; peptone, 5.0; sodium chloride, 8.0 and agar 15.0. Before each experiment the bacteria were cultured in liquid medium for $24 \mathrm{~h}$ and used as source of inoculums.

The minimum inhibitory concentration (MIC) and minimum bactericidal concentration (MBC) were determined following the guidelines recommended by the CLSI (Clinical and Laboratory Standard Institute) normative [14].

To determine the MIC and MBC Mueller Hilton broth (MHB) were used. The final concentration of bacteria in each macrobroth dilution tube was approximately $5 \times 10^{5}$ $\mathrm{cfu} / \mathrm{ml}$ of MHB. Serial dilutions of herbal infusions were carried out. MIC is interpreted as the lowest concentration of 
Table 1. Antioxidant activity of herb infusions and the modification by the addition of Lemon, sugar or sweetener.

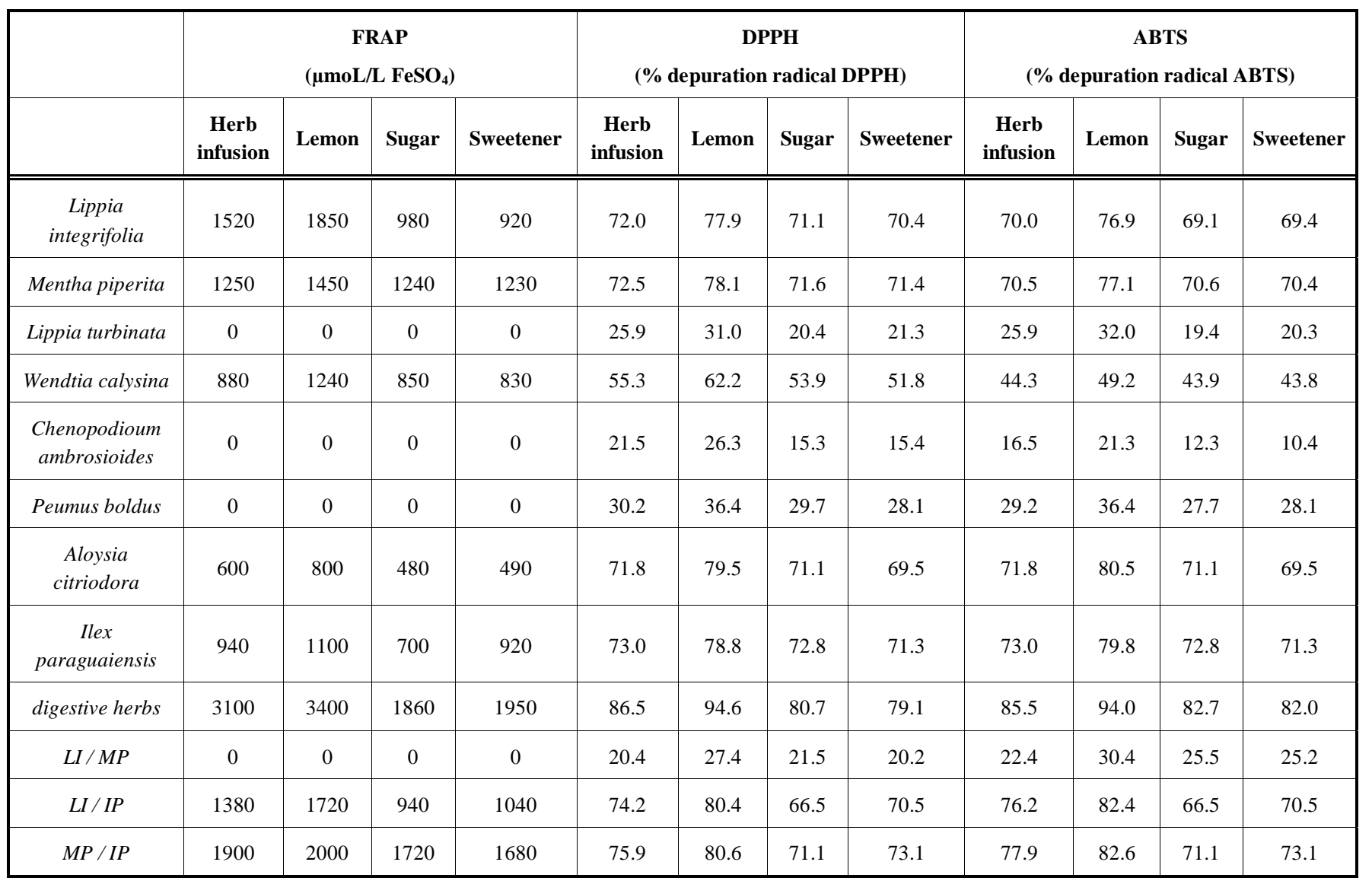

phenolic compounds which produce growth inhibition of the microorganism (no evident turbidity) after $24 \mathrm{~h}$ of incubation at $37^{\circ} \mathrm{C}$. From the dilutions in which no growth was observed, an aliquot of $50 \mu \mathrm{L}$ are inoculated MHB-agar plates. The plates are incubated for $24 \mathrm{~h}$ at $37^{\circ} \mathrm{C}$. The MBC is the minimum concentration of phenolic compounds present in herbal infusions needed to produce $99.9 \%$ kill of the initial inoculums. Assays were performed in triplicate and the MIC and MBC determined in herbal infusions treated with activated charcoal were used as control.

\section{Statistical Analysis}

The experiments were performed in triplicate and statistical analysis was carried out using MS-Excel software.

\section{RESULTS AND DISCUSSION}

\section{Phenolic Compounds Concentrations}

Fig. (1) shows the differences in the total phenolic compounds (a), phenolic acid (b) and flavonoid (c) compounds concentrations between herb infusions and herbs infusions added with additives such as lemon, sugar or sweetener. In a previous work, Rodríguez Vaquero et al. [15] described that the total phenolic concentration in herb infusions ranged from 50.3 to $925.0 \mathrm{mg}$ GAE/L, Ilex paraguaiensis, Lippia integrifolia and Mentha piperita had the highest concentration, whereas Lippia turbinata and Chenopodioum ambrosioides had the lowest phenolic compounds concentration.

In all infusions concentration, majority flavonoid compounds were compared to the concentration of phenolic acids. The removal of phenolic compounds from the infusions was effective after the clarification process. Our results showed that the addition of lemon increased around $10 \%$ the phenolic compound concentration in all cases. The addition of sweetener slightly decreased the concentration of phenolic compounds in all herbs infusions, but this decrease was not significant and it could be some interference between compounds. The addition of sugar did not modify significantly the phenolic concentration of herb infusions.

Antihypertensive activity. Fig. (2) shows the antihypertensive activity of individual herb infusions and mixtures of herb infusions. Results show that ACEI activity of Ilex paraguaiensis, Lippia integrifolia, Mentha piperita and the three selected combinations was higher than $80 \%$. The lowest activity was shown in the presence of Chenopodioum ambrosioides and Minthostachys verticillatta (between 15 and 37\%). The extraction of phenolic compounds of herb infusions produced the total loss of the ACEI activity, demonstrating that phenolic compounds present in Argentinean herb infusions were the responsible of this activity. The addition of lemon increased the ACEI activity to the herb infusions preparation around $10 \%$; this 

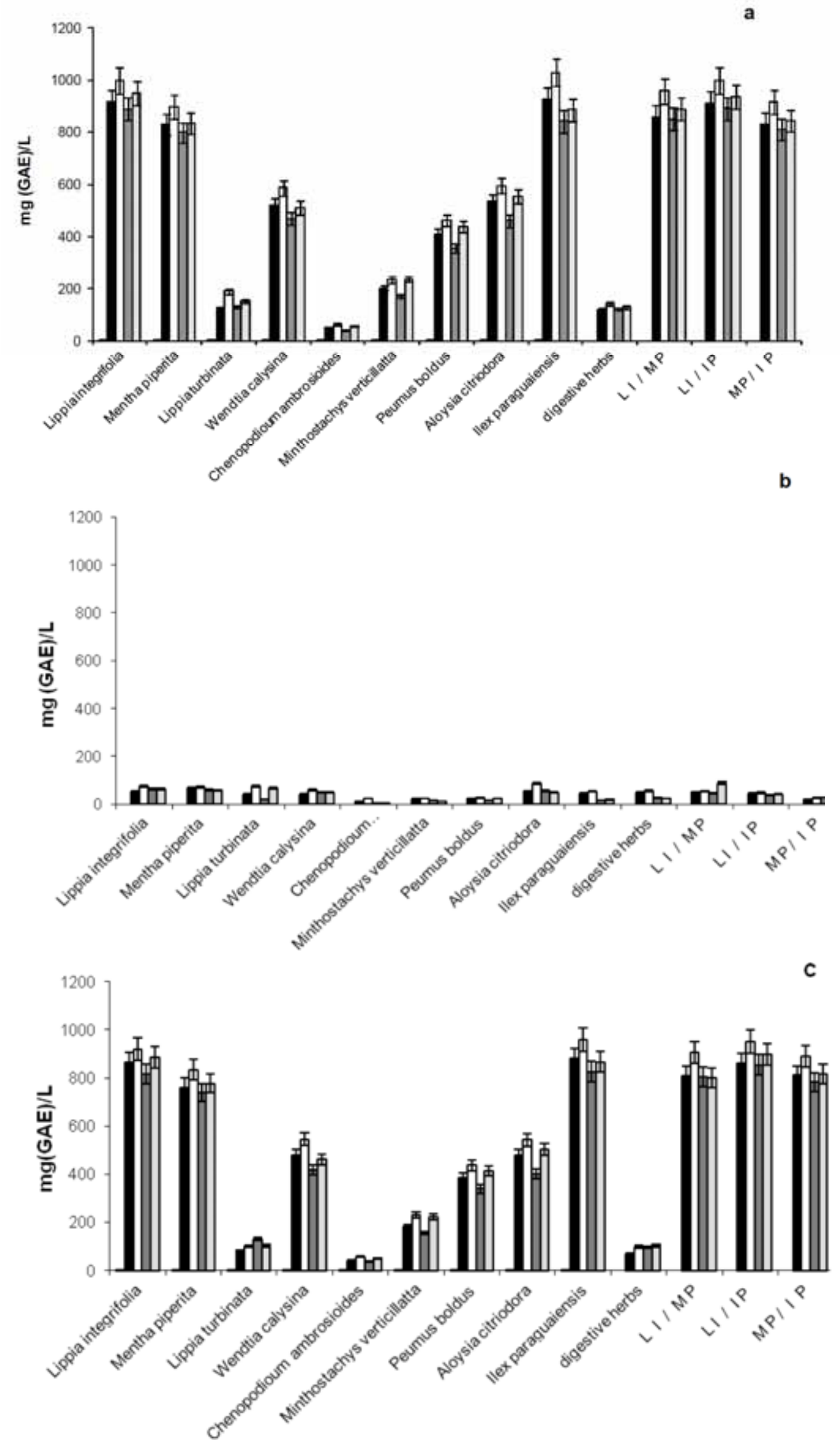

Fig. (1). Total phenolic compounds (a), phenolic acids (b) and flavonoids (c) concentrations in Argentinean herb infusions without additives $(\varpi)$, with lemon $(\square)$, sugar $(\square)$ or sweetener $(\square)$. All determination was at least at triplicate. 


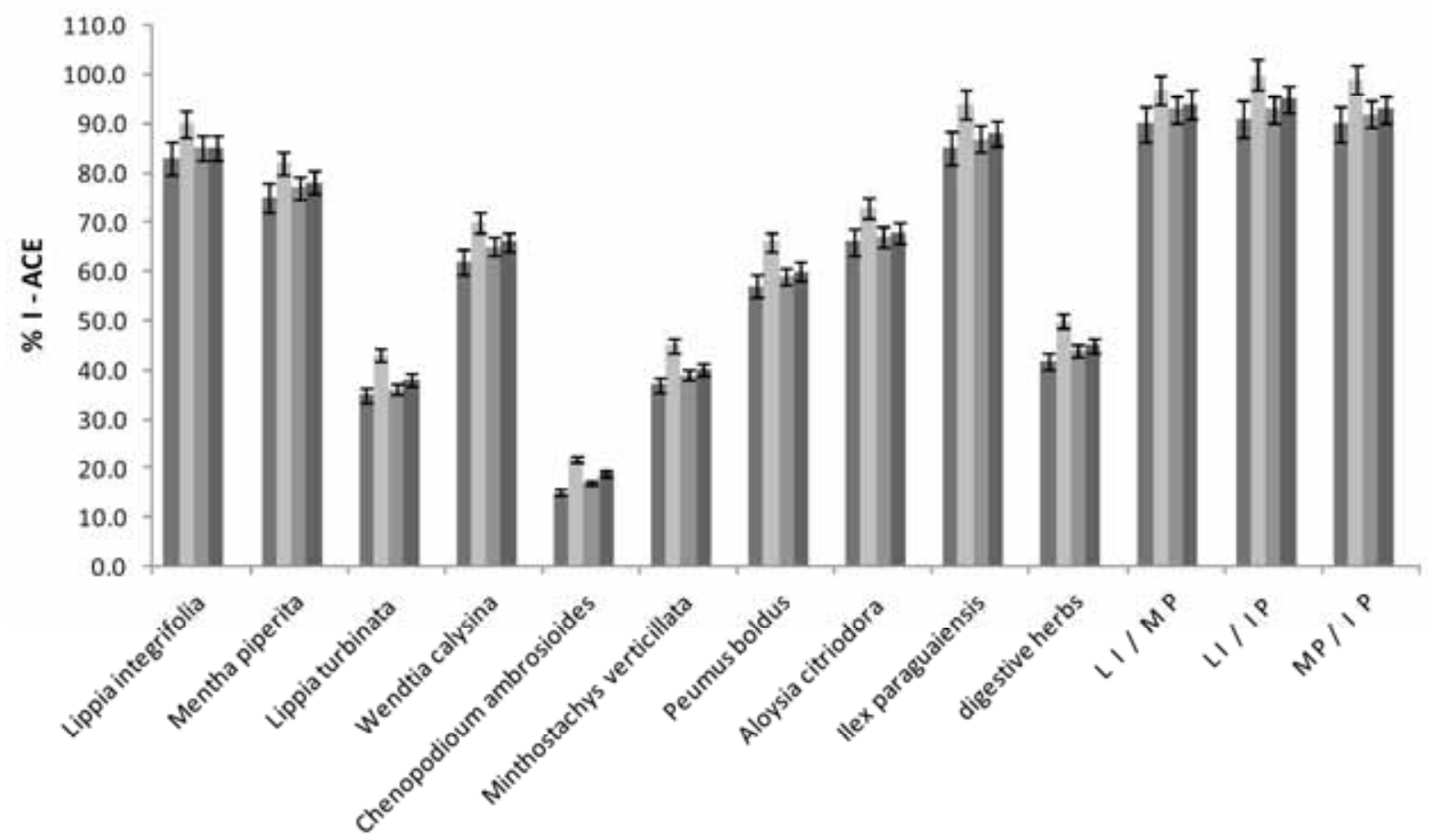

Fig. (2). Angiotensin I-converting enzyme (ACE) inhibition (\%) by herb infusions ( $\square$ ), herb infusions added with lemon ( $\square$ ), sugar ( $\square$ ) or sweetener $(\square)$. All determination was at least at triplicate.

could be due to the phenolic compounds found in lemon, but the addition of sugar or sweetener did not modify this activity.

Our results show a high correlation between the phenolic concentration and the antihypertensive activity and this fact was in agreement with Vallejo et al. [18] that demonstrated a good correlation between the phenolic compounds concentrations in juice fruit and the antihypertensive activity.

Antioxidant capacity. Three methods (FRAP, DPPH and ABTS radical scavenging assays) have been used to measure the effect of the additives in herb infusions on the antioxidant activity (Fig. 3).

In a previous work, Rodríguez Vaquero et al. [15] reported that Ilex paraguaiensis posseses the highest ferric reducing power and Peumus boldus the lowest ferric reduced power values, whereas it was not detected in Lippia turbinata, Chenopodioum ambrosioides and Minthostachys verticillatta infusions. The greatest DPPH free radical scavenging activity was found with Ilex paraguaiensis, whereas Lippia turbinata, Chenopodioum ambrosioides and Minthostachys verticillatta showed a lowest radical scavenging activity. The radical scavenging activity on clarified infusions was lower than $8 \%$.

Our results showed that infusions prepared with Ilex paraguaiensis, Lippia integrifolia, Mentha piperita, Aloysia citriodora, Peumus boldus, and the three combinations selected posses a great free ABTS radical scavenging activity (higher than 70\%). Lippia turbinata, Wendtia calysina, Chenopodioum ambrosioide, Minthostachys verticillatta and digestive herbs show the lowest a free ABTS radical scavenging activity (lower than 50\%).
The antioxidant activity determinants by the three methods increased this activity with the addition of lemon to herb infusions preparation and the addition of sugar or sweetener did not modify this activity.

We found a high correlation between phenolic compounds concentration in herb infusions and beneficial so we are in agreement with results observed by Li et al. [16] with phenolic compounds of Chinese medicinal plants and with those of Yoo et al. [17] that found a higher correlation between antioxidant capacity and total phenolic and total flavonoids content in commercial herbs.

Antibacterial property. The modifications in MIC and MBC against $E$. coli of selected herb infusions by additives are presented in Table 2. Ilex paraguaiensis, Lippia integrifolia, Mentha piperita and Peumus boldus infusions produced inhibition in the growth of $E$. coli, whereas Wendtia calysina and Aloysia citriodora did not modify the growth of this bacterium. The addition of lemon produces an increase in the growth inhibition observed with Ilex paraguaiensis and Lippia integrifolia infusion, but did not modify the inhibition observed with Mentha piperita or Peumus boldus infusions. Only Ilex paraguaiensis and Lippia integrifolia infusions produced cellular death and this effect was increased by 50\% with the addition of lemon. With the addition of sugar or sweetener a slight increase in the growth of the bacterium was observed, may be due to the consumption of sugar or sweetener.

With clarified infusions, inhibition of the growth of $E$. coli was not observed, so the antibacterial effect was attributed to the phenolic compounds in the infusions. 


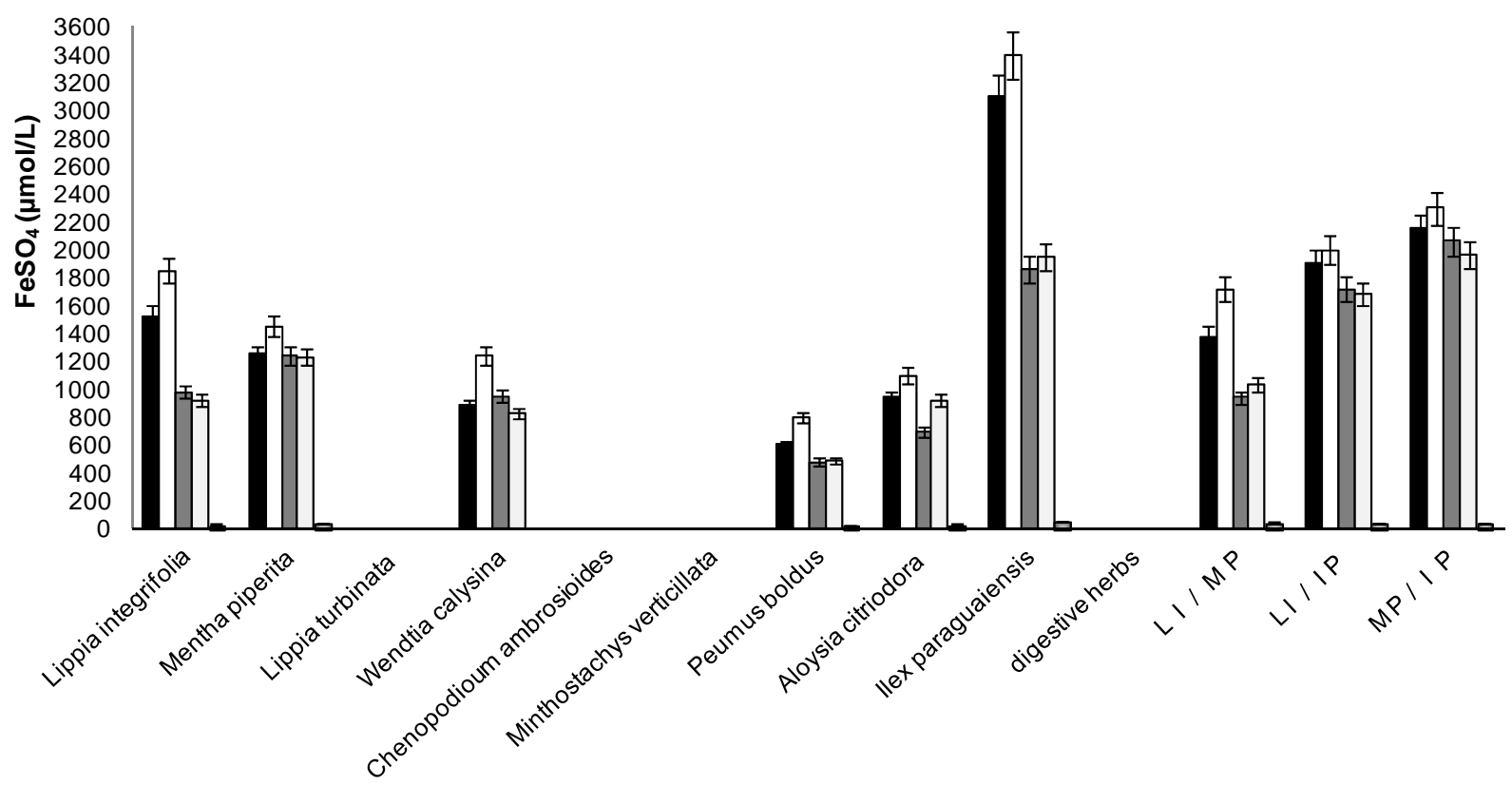

Fig. (3). Antioxidant capacity of herbs infusions. Ferric Reducing Antioxidant Power of herb infusions $(\mu \mathrm{moL} / \mathrm{L} \mathrm{FeSO})_{4}(\mathbf{a}), \mathrm{Percentage}$ inhibition of DPPH radical (\%) (b) and Percentage inhibition of DPPH radical (\%).

Table 2. Modification of the MIC and MBC of selected infusions against $E$. coli by the addition of additives to herb infusions.

\begin{tabular}{|c|c|c|c|c|c|c|c|c|c|c|c|c|c|c|c|c|}
\hline & \multicolumn{8}{|c|}{ Herb Infusions } & \multicolumn{8}{|c|}{ Clarified Herb Infusions } \\
\hline & \multicolumn{4}{|c|}{ MIC } & \multicolumn{4}{|c|}{ MBC } & \multicolumn{4}{|c|}{ MIC } & \multicolumn{4}{|c|}{ MBC } \\
\hline & $\begin{array}{c}\text { Herb } \\
\text { infusion }\end{array}$ & Lemon & Sugar & Sweetener & $\begin{array}{c}\text { Herb } \\
\text { infusion }\end{array}$ & Lemon & Sugar & Sweetener & $\begin{array}{c}\text { Herb } \\
\text { infusion }\end{array}$ & Lemon & Sugar & Sweetener & $\begin{array}{c}\text { Herb } \\
\text { infusion }\end{array}$ & Lemon & Sugar & Sweetener \\
\hline $\begin{array}{c}\text { Lippia } \\
\text { integrifolia }\end{array}$ & $916^{*}$ & 468 & nd & nd & 916 & 468 & nd & nd & nd & nd & nd & nd & nd & nd & nd & nd \\
\hline Mentha piperita & 830 & 830 & nd & nd & 830 & 415 & nd & nd & nd & nd & nd & nd & nd & nd & nd & nd \\
\hline Wendtia calysina & nd & nd & nd & nd & nd & nd & nd & nd & nd & nd & nd & nd & nd & nd & nd & nd \\
\hline Peumus boldus & 409 & 409 & nd & nd & nd & nd & nd & nd & nd & nd & nd & nd & nd & nd & nd & nd \\
\hline $\begin{array}{c}\text { Aloysia } \\
\text { citriodora }\end{array}$ & nd & nd & nd & nd & nd & nd & nd & nd & nd & nd & nd & nd & nd & nd & nd & nd \\
\hline $\begin{array}{c}\text { Ilex } \\
\text { paraguaiensis }\end{array}$ & 925 & 462.5 & nd & nd & 925 & 462.5 & nd & nd & nd & nd & nd & nd & nd & nd & nd & nd \\
\hline
\end{tabular}

*mg of equivalent of gallic acid (GAE) / L, nd: not detected.

We are in agreement with Vallejo et al. [18] who reported that the antioxidant, antihypertensive and antimicrobial activity of Argentinean juice fruit was related with the phenolic compound concentration, but also with the phenolic profile. Rodríguez Vaquero et al. [19] reported that E. coli was sensible to commercial phenolic compound and to phenolic compounds from red wines.

Our results indicate that the addition of a spoonful of lemon is recommended, this fact increases the phenolic concentration in herb infusions and increases beneficial activities of the infusion to human health such as the antioxidant, antihypertensive activities and inhibits the growth of E. coli on herb infusions.

The biological properties of the Argentinean herbs infusions demonstrated in this study, particularly from Ilex paraguaiensis and Lippia integrifolia, could enable their use as potential natural antioxidants and antihypertensive agents with application in the food and pharmaceutical industries, to favoring and/or replacing the biological activities of the synthetic drugs. 


\section{CONFLICT OF INTEREST}

The authors confirm that this article content has no conflicts of interest.

\section{ACKNOWLEDGEMENTS}

This work was supported by grants from Consejo de Investigaciones de la Universidad Nacional de Tucumán, Argentina (CIUNT) and Consejo Nacional de Investigaciones Científicas y Técnicas (CONICET).

\section{REFERENCES}

[1] Djeridane, A.; Yousfi, M.; Nadjemi, B.; Boutassouna, D.; Stocker, P.; Vidal, N. Antioxidant activity of some Algerian medicinal plants extracts containing phenolic compounds. Food Chem, 2006, $97,654-660$

[2] Moraes-De-Souza, R.A.; Oldoni, T.L.C.; Cabral, I.S.R.; Alencar, S.M. Compostos fenólicos totais e atividade Antioxidante de chás comercializados no Brasil. Boletimdo Centro Pesquisa Processamento de Alimentos, 2011, 29, 229-236.

[3] Ruiz-Terán, F.; Medrano-Martínez, A.; Navarro-Ocaña, A. Antioxidant and free radical scavenging activities of plant extracts used in traditional medicine in Mexico. Afri J Biotechnol, 2008, 7, 1886-1893.

[4] Silva, E.M.; Souza, J.N.S.; Rogez, H.; Rees, J.F.; Larondelle, Y. Antioxidant activities and polyphenol contents of fifteen selected plant species from the Amazonian region. Food Chem, 2007, 101, 1012-1018.

[5] Moller, P.; Loft, S. Dietary antioxidants and beneficial effects on oxidatively damaged DNA. Free Radic Biol Med, 2006, 41, 388415.

[6] Monteiro, M.; Farah, A.; Perrone, D.; Trugo, L.C.; Donangelo, C. Chlorogenic acid compounds from coffee are differentially absorbed metabolized in humans. Nutrition, 2007, 37, 2196-2201.

[7] Singleton, V.L.; Rossi, J.A. Colorimetry of total phenolics with phosphomolybdic phosphotungstic acid reagents. Am J Enol Vitic, 1965, 16, 144-158.
[8] Zoecklein, B.W.; Fugelsang, K.C.; Gump, B.H.; Nury, F.S Phenolic compounds and wine color. In: Production wine analysis. Ed. Zoecklein, Bruce. Van Nostrand Reinhold. New York, 1990, 129-168.

[9] Cushman, D.W.; Cheung, H.S. Spectrophotometric assay and properties of the angiotensin I-converting enzyme of rabbit lung. Biochem Pharmacol, 1971, 20, 1637-1648.

[10] Hernández-Ledesma, B.; Martín-Alvarez, P.J.; Pueyo, E. Assesment of the spectrophotometric method for determination of angiotensin-converting-enzyme activity: influence of the inhibition type. J Agric Food Chem, 2003, 51, 4175-4179.

[11] Benzie, I.F.; Strain, J.J. The ferric reducing ability of plasma (FRAP) as measurement of "antioxidant power": The Frap assay. Anal Biochem, 1996, 239, 70-76.

[12] Von Gadow, A.; Joubert, E.; Hansmann, C.F. Comparison of antioxidant activity of aspalathin with that of other plant phenols of Rooibosed tea (Aspalathon linearis), $\alpha$-tocopherol, BHT, and BHA. J Agric Food Chem, 1997, 45, 632-638.

[13] Re, R.; Pellegrini, N.; Proteggente, A.; Pannala, A.; Yang, M.; Rice-Evans, C. Antioxidant activity applying an improved ABTS radical cation decolorization assay. Free Radic Biol Medic, 1999, 26(9-10), 1231-1237.

[14] Clinical and Laboratory Standards Institute (CLSI). Performance standards for antimicrobial susceptibility testing, seventeenth informational supplement, M100-S17, 2007, Wayne, PA: CLSI

[15] Rodríguez-Vaquero, M.J.; Tomassini-Seravalle, L.R.; Manca de Nadra, M.C.; Strasser de Saad, A.M. antioxidant capacity and antibacterial activity of phenolic compounds from argentinean herbs infusions. Food Control, 2010, 21, 779-785

[16] Li, H.B.; Wong, C.C.; Cheng, K.W.; Chen, F. Antioxidant properties in vitro and total phenolic contents in methanol extracts from medicinal plants. Food Sci Technol, 2008, 41, 385-390.

[17] Yoo, K.M.; Lee, C.H.; Lee, H.; Moon, B.; Lee, C.Y. Relative antioxidant and cytoprotective activities of common herbs. Food Chem, 2008, 106, 929-936.

[18] Vallejo, C.V.; Aredes Fernández, P.A.; Farias, M.E.; RodríguezVaquero, M.J. biofilm inhibition of spoilage bacteria by argentinean fruit juices with antihypertensive activity. Current Pharm Biotechnol, 2013, 14, In press.

[19] Rodríguez-Vaquero, M.J.; Manca de Nadra, M.C. Growth parameter and viability modifications of Escherichia coli by phenolic compounds and argentine wine extracts. Appl Biochem Biotechnol, 2008, 151 (2), 342-352.

Received: March 19, 2014

Revised: July 02, 2014

Accepted: July 16, 2014

(C) Rodríguez-Vaquero et al.; Licensee Bentham Open.

This is an open access article licensed under the terms of the Creative Commons Attribution Non-Commercial License (http://creativecommons.org/licenses/bync/3.0/), which permits unrestricted, non-commercial use, distribution and reproduction in any medium, provided the work is properly cited. 